\title{
A new evidence of passing the Maastichtian-Paleocene boundary by larger benthic foraminifers: The case of Elazigina from the Maastrichtian Tarbur Formation of Iran
}

Lorenzo Consorti and Koorosh Rashidi

Acta Palaeontologica Polonica 63 (3), 2018: 595-605 doi:https://doi.org/10.4202/app.00487.2018

We describe a new Maastrichtian species of the benthic foraminifer Elazigina siderea from Tarbur Formation. Its main characters are the presence of heavy feathered umbilical sutures, a wide umbilical plug, and umbilical piles. This species, formerly reported from Turkey as Smoutina cruysi , constitutes the oldest known record of the genus Elazigina. Elazigina siderea sp. nov. comes from the Arabian domain and its presence is probably related to the migration of the Cretaceous foraminifer Orbitokathina. Prior to this study, the oldest representatives of this genus were only known from the Paleocene. Therefore, the presence of the new taxon in the Maastrichtian suggests the genus Elazigina passed the Cretaceous-Paleogene boundary, and survived to the environmental crisis associated with a great biosphere mass extinction that wiped out most of the Late Cretaceous larger foraminifers. This is supported by shell features displayed by Elazigina siderea sp. nov., interpreted as adaptation to thrive under elevated trophic levels, like the species of another benthic foraminifer Laffitteina.

Key words: Foraminifera, Globothalamea, Rotaliida, extinction, Cretaceous, Iran.

Lorenzo Consorti [lorenzo.consorti.es@gmail.com], Department of Earth, Environmental and Resources Sciences, University Federico II, Complesso di Monte Sant'Angelo (Edificio L), Via Cinthia, 21, 80126 Naples, Italy. Koorosh Rashidi [koo.rashidi@gmail.com], Department of Geology, Payame Noor University, Po Box 19395-3697, Tehran, Iran.

This is an open-access article distributed under the terms of the Creative Commons Attribution License (for details please see creativecommons.org), which permits unrestricted use, distribution, and reproduction in any medium, provided the original author and source are credited. 
Fof Full text $(1,541.7 \mathrm{kB})$ 